\title{
Kelembagaan Pemerintahan Desa dan Pemberdayaan Masyarakat dalam Implementasi Undang-Undang Desa
}

\author{
Suharto Suharto \\ Program Studi Ilmu Politik, Universitas Wahid Hasyim \\ Email : hartoss@gmail.com
}

Dikirim : 16 April 2021 | Direvisi : 12 Mei 2021 | Diterima : 10 Juni 2021

\begin{abstract}
ABSTRAK
Implementasi kebijakan Undang-Undang Desa memerlukan dukungan dari kelembagaan pemerintahan desa dengan pola strategi pemberdayaan masyarakat desa sesuai potensi lokal yang ada. Pelaksanaan Undang-Undang Desa menjadi harapan semua masyarakat desa untuk mewujudkan desa mandiri yang memiliki jatidiri, merupakan penghargaan dalam hak asal usul desa dengan pola pendekatan pemberdayaan masyarakat desa yang memposisikan masyarakat desa sebagai subjek/pelaku utama bukan hanya sebagai obyek /sasaran saja dari program kegiatan pembangunan desa. Penelitian ini dengan metode penelitian deskriptif kualitatif, dengan tujuan untuk mengetahui bagaimana kemampuan kelembagaan pemerintahan desa dalam memberdayakan masyarakat desa menuju desa mandiri sesuai amanah Undang-Undang Desa. Keberhasilan implementasi Undang-Undang Desa secara nyata dipengaruhi adanya dukungan dari pemerintahan kelembagaan desa yaitu antara lain Pemerintah Desa/ Perangkat Desa, Badan Permusyawaratan Desa (BPD), LPMD/LKMD, PKK, Karangtaruna, BKM/UPK PNPM, Dukuh, RW, RT dan kelompok-kelompok swadaya masyarakat lainnya.
\end{abstract}

Kata Kunci: Pemerintahan Desa; Pemberdayaan Masyarakat; Undang-Undang Desa

\begin{abstract}
The implementation of the Village Law policy requires support from village government institutions with a pattern of village community empowerment strategies according to existing local potential. The implementation of the Village Law is the hope of all village communities to create an independent village that has an identity, it is an appreciation for the right of the origin of the village with a village community empowerment approach that positions the village community as the main subject / actor not only as an object / target of program activities. village development. This research uses descriptive qualitative research methods, with the aim of finding out how the ability of village government institutions to empower village communities to become independent villages according to the mandate of the Village Law. The successful implementation of the Village Law is significantly influenced by the support of village institutional governance, namely, among others, the Village Government / Village Apparatus, Village Consultative Body (BPD), LPMD / LKMD, PKK, Karangtaruna, BKM / UPK PNPM, Dukuh, RW, RT and other non-governmental groups.
\end{abstract}

Keywords: Village Government; Community Empowerment; Village Law 


\section{PENDAHULUAN}

Desa sering diucap dengan sebutan dusun, tanah asal, tanah kelahiran dan tanah kampung halaman. Desa bisa dikatakan sekelompok rumah diluar kota yang merupakan kesatuan kampung, dusun atau udik (dalam arti daerah pedalaman). Dalam pembangunan masyarakat desa diharapkan juga ikut mengawasi dan menggambil peran aktif melalui musyawarah desa agar pelaksanaan pembangunan bisa benar-benar efektif dan tepat sasaran serta dilakukan secara transparan dan akuntabel dengan pola pendekatan pemberdayaan masyarakat. Maka pemberdayaan masyarakat di pedesaan adalah pemberdayaan sumberdaya (potensi) lokal dalam meningkatkan partisipasi, memupuk kepedulian semua pihak untuk kemandirian (berdikari) masyarakat. Melihat realitas tersebut, maka implementasi UU RI Nomor: 6 Tahun 2014 tentang Desa perlu adanya dukungan dari semua fihak terutama warga masyarakat desa dalam berperan sebagai pelaku pembangunan didesa.

Amanat UU RI Nomor 6 Tahun 2014 tentang Desa, yaitu pertama dalam rangka membina dan meningkatkan perekonomian desa serta mengintegrasikannya. Pemerintah desa dituntut melakukan inovasi dan berkreativitas untuk menciptakan sektor ekonomi produktif pedesaan, seperti budi daya produk-produk yang berbasis kearifan lokal, antara lain hasil kerajinan industri pangan/minuman tradisional, produk hasil bumi dan pertanian dan sebagainya. Kedua, dapat mengembangkan sumber pendapatan desa dan perwujudan pembangunan desa secara partisipasif. Pemerintah desa harus bisa memanfaatkan dan mendayagunakan aset sebagai sumber pendapatan yang bisa digunakan untuk membangun sarana dan prasaranan. Dalam aset desa berupa tanah kas, tanah ulayat, pasar atau pasar hewan, bangunan desa, hutan milik desa, mata air/pemandian umum, dan aset lain milik desa

Ketiga. Pembangunan kawasan pedesaan yang meliputi penggunaan dan pemanfaatan wilayah desa dalam rangka penetapan kawasan pembangunan sesuai dengan tata ruang kabupaten/kota, membangun infrastruktur, meningkatkan ekonomi pedesaan, dan pengembangan teknologi tepat guna, serta pemberdayaan masyarakat desa untuk meningkatkan akses terhadap pelayanan dan kegiatan ekonomi ( Pasal 79 UU Nomor 6 Tahun 2014 ). Keempat. Mendirikan badan usaha milik desa (BUMDes yang dikelola dengan semangat kekeluargaan dan gotong royong. Hasil usaha badan tersebut dapat dimanfaatkan untuk pengembangan usaha, pembangunan desa, pemberdayaan masyarakat, dan membantu masyarakat miskin melalui hibah, bantuan sosial, atau dana bergulir yang ditetapkan dalam anggaran pendapatan dan belanja desa/APBDes.(PP No 43 Tahun 2014).

Adapun Kelembagaan pemerintahan desa, merupakan faktor pendorong (push factor) dan motor penggerak. Dalam Peraturan Pemerintah No. 43 Tahun 2014 tentang peraturan pelaksanaan UU Desa, pada Pasal 78 dinyatakan bahwa tujuan dari pembangunan desa adalah meningkatkan kesejahteraan masyarakat Desa dan kualitas hidup manusia serta penanggulangan kemiskinan melalui pemenuhan kebutuhan dasar, pembangunan sarana dan prasarana Desa, pengembangan ekonomi lokal, serta pemanfaatan sumber daya alam dan lingkungan secara berkelanjutan. Sedangkan dalam Pasal 83 dinyatakan bahwa Pembangunan Kawasan Perdesaan dilaksanakan dalam upaya mempercepat dan meningkatkan kualitas pelayanan, pembangunan, dan pemberdayaan masyarakat Desa di Kawasan Perdesaan melalui pendekatan pembangunan partisipatif. (PP No 43 Tahun 2014). 
Melalui pemberdayaan masyarakat Desa diharapkan mampu membawa perubahan nyata sehingga harkat dan martabat mereka pulih kembali. Pemberdayaan masyarakat merupakan pendekatan yang memperhatikan seluruh aspek kehidupan masyarakat dengan sasaran seluruh lapisan masyarakat, bermotifkan pemandirian (keberdikarian), sehingga mampu membangkitkan kemampuan self-help. untuk meningkatkan kualitas hidup masyarakat ( modernisasi ) yang mengacu pada cara berpikir, bersikap, berperilaku untuk maju. Maka pemberdayaan merupakan titik strategis yang harus diperbarui dan diperluas. Sehingga esensi pemberdayaan masyarakat di pedesaan adalah pendayagunaan sumberdaya (potensi) lokal, meningkatkan partisipasi, memupuk kepedulian semua pihak untuk kemandirian masyarakat dan pemberdayaan kelembagaan lokal (desa). Maka peran penting dari kepedulian semua fihak yaitu masyarakat, pemerintah, swasta dan termasuk pendidikan tinggi (Perguruan Tinggi) untuk menyumbangkan pemikiran, teknologinya ataupun tenaganya dalam menyiapkan insan yang siap mendampingi masyarakat dengan pendekatan pemberdayaan masyarakat sesuai amanah dalam UU Desa. Lewat Tri Dharmanya Perguruan Tinggi jelas memiliki kapabilitas dan kapasitas dalam mendukung percepatan pembangunan desa yang kita harapkan.

Penelitian yang telah kita dilakukan menunjukkan bahwa dengan melihat kondisi desa yang ada pada saat sekarang secara nasional, masih perlu ada peningkatan dukungan dalam rangka implementasi UU Desa. Maka perlu adanya suatu strategi /model pemberdayaan kelembagaan dalam rangka implementasi UU RI No. 6 Tahun 2014 tentang desa. Demikian pula sangat diperlukan suatu pola strategi /model pemberdayaan kelembagaan pemerintahan desa. UU Nomer 6 Tahun 2014 tentang Desa merupakan out put dari kebijakan publik dari pemerintah yang disambut masyarakat desa dengan penuh harapan utk kemandirian desa. Dan sekarang ini tahapan implementasi dari kebijakan tersebut, dan sudah sewajarnya mulai di evaluasi hasilnya. Pada awal memberlakukan UU Desa memang diperlukan kondisi kesiapan desa, karena UU Desa ini bisa berjalan dengan baik dan efektif manakala ada kesiapan dari desa, mengingat didalamnya mengatur pola pendekatan pemberdayaan masyarakat yang memposisikan warga masyarakat tidak hanya sebagai obyek pembangunan namun juga sebagai subyek / pelaku pembangunan. Dalam rangka keberhasilan implementasi UU Desa tersebut salah satunya diperlukan suatu dukungan yang optimal dari Kelembagaan Pemerintahan Desa yang bisa meningkatkan kapasitas dan kapabilitas kelembagaan desa dalam implementasi UU Desa sesuai amanah didalamnya.

Banyak Undang-Undang yang mengatur tentang Desa sejak Indonesia merdeka 17 Agustus 1945 memang Undang-Undang Desa Nomor 6 Tahun 2014 adalah yang terbaik. Amanah Undang-Undang No. 6 Tahun 2014 tentang Desa, dimana dalam pasal 78 dinyatakan bahwa tujuan dari pembangunan desa adalah meningkatkan kesejahteraan masyarakat Desa dan kualitas hidup manusia serta penanggulangan kemiskinan melalui pemenuhan kebutuhan dasar, pembangunan sarana dan prasarana Desa, pengembangan ekonomi lokal, serta pemanfaatan sumber daya alam dan lingkungan secara berkelanjutan.

Dalam pasal 83 dinyatakan bahwa Pembangunan Kawasan Perdesaan dilaksanakan dalam upaya mempercepat dan meningkatkan kualitas pelayanan, pembangunan, dan pemberdayaan masyarakat Desa di Kawasan Perdesaan melalui pendekatan pembangunan partisipatif. UU Desa juga memberi amanah kepada Pemerintah, Pemda Provinsi, dan Pemda Kabupaten/ Kota untuk memberdayakan masyarakat Desa, yang dilaksanakan dengan 
pendampingan dalam perencanaan, pelaksanaan dan pemantauan pembangunan Desa dan Kawasan Perdesaan (pasal 122, pemberdayaan masyarakat Desa dan pendampingan masyarakat Desa diatur lebih lanjut dalam Peraturan Pemerintah (PP No. 43 Tahun 2014 khususnya pasal 126 s.d 131).

Melalui pemberdayaan masyarakat Desa diharapkan mampu membawa perubahan nyata sehingga harkat dan martabat mereka pulih kembali. Pemberdayaan masyarakat merupakan pendekatan yang memperhatikan seluruh aspek kehidupan masyarakat dengan sasaran seluruh lapisan masyarakat, bermotifkan pemandirian (keberdikarian), sehingga mampu membangkitkan kemampuan self-help. untuk meningkatkan kualitas hidup masyarakat (modernisasi) yang mengacu pada cara berpikir, bersikap, berperilaku untuk maju. Maka bidang pemberdayaan merupakan titik strategis yang harus diperbarui dan diperluas (Rizkita, 2016; Sujarweni, 2015). Sehingga esensi pemberdayaan masyarakat di pedesaan adalah pendayagunaan sumberdaya (potensi) lokal, meningkatkan partisipasi, memupuk kepedulian semua pihak untuk kemandirian (berdikari) masyarakat.

Pembangunan Kawasan Perdesaan sesuai amanah UU No.6 Th. 2014 tentang Desa dan best practices oleh Program PNPM Mandiri yang telah berlalu bisa sejalan dan dapat bersinergi dengan program unggulan Gubernur Jawa Tengah yaitu "Desa Berdikari". Filosofi aktualisasi Desa Berdikari adalah merupakan gerakan pemberdayaan desa dengan proses Rembugan warga secara terus menerus/berkesinambungan, dalam rangka pengelolaan sumberdaya desa secara mandiri (produktif) menuju keberdikarian desa, melalui pendampingan oleh Kader Desa Berdikari (KDB). Desa Berdikari dicerminkan dengan kemampuan Desa untuk : (1) Membangun berdasarkan kekuatan dan sumber daya yang ada di Jateng, agar terhindar dari jebakan ketergantungan dengan pihak eksternal; (2) Mengekplorasi seluruh potensi, baik ilmu pengetahuan, teknologi, kearifan lokal, SDA dan lingkungan, serta SDM Jateng dimanapun bermukim, untuk mendukung dan meningkatkan kekuatan sendiri; (3) Melakukan kerjasama dengan para pihak, dalam dan luar negeri, secara saling menghormati dan menguntungkan dalam jangka pendek maupun panjang. Target perwujudan Desa Berdikari (sesuai RPJMD Provinsi Jateng Tahun 2013 - 2018) adalah sebanyak 100 desa pada akhir tahun 2018.

Melalui pemberdayaan masyarakat desa dengan memperhatikan seluruh aspek kehidupan masyarakat dengan sasaran seluruh lapisan masyarakat bermotifkan pemandirian (berdikari), sehingga mampu membangkitkan kemampuan self-help. untuk meningkatkan kualitas hidup masyarakat (modernisasi) yang mengacu pada cara berpikir, bersikap, berperilaku, maka bidang pemberdayaan merupakan titik strategis yang harus diperbarui dan diperluas (Aspariyana, 2018). Sehingga esensi pemberdayaan masyarakat di perdesaan adalah pendayagunaan sumberdaya (potensi) lokal, meningkatkan partisipasi dan kemandirian (berdikari). Maka peran penting dari kepedulian smua fihak yaitu masyarakat, pemerintah, swasta dan termasuk pendidikan tinggi (Perguruan Tinggi) untuk menyumbangkan pemikiran, teknologinya ataupun tenaganya dalam menyiapkan insan yang siap mendampingi masyarakat dengan pendekatan pemberdayaan masyarakat sesuai amanah dalam UU Desa. Lewat Tri Dharmanya Perguruan Tinggi jelas memiliki kapabilitas dan kapasitas dalam mendukung percepatan pembangunan desa. Melihat kondisi desa yang ada sekarang secara nasional masih diperlukan adanya persiapan secara menerus untuk meningkatkan kualitas dan kuantitas dalam rangka implementasi UU Desa. 


\section{METODE PENELITIAN}

Penelitian ini dengan metode penelitian deskriptif kualitatif yaitu penelitian yang menggambarkan tentang kelembagaan pemerintahan desa dalam pemberdayaan masyarakat (Moleong, 2012; Sugiyono, 2012). Teknik pengumpulan data yang dipergunakan dalam penelitian ini adalah wawancara mendalam, dokumentasi untuk mengumpulkan data sekunder tentang hasil-hasil pelaksanaan program kegiatan dan data lain dari kelembagaan desa terkait pelaksanaan UU Desa. Teknik analisis data dengan analisis kualitatif dipergunakan untuk mengolah dan menganalisis data yang bersifat kualitatif dari hasil wawancara mendalam (FGD) dan dokumentasi (Hair et al., 2010; Weimer \& Vining, 2017).

\section{HASIL DAN PEMBAHASAN}

\section{Kelembagaan Pemerintahan Desa Dan Pemberdayaan Masyarakat Dalam Implementasi UU Desa.}

Kesiapan kelembagaan desa dan perangkat desa merupakan syarat mutlak berhasilnya implementasi UU Desa karena merekalah ujung tombak pelaksanaan UU Desa tersebut sesuai dengan aturan pelaksanaan yang ada. Kemampuan (kapasitas) dari Lembaga Desa dan Perangkat Desa dalam menyikapi dan menyiapkan terkait implementasi UU Desa sangat menentukan tingkat keberhasilannya. Dalam hal ini kelembagaan desa yaitu antara lain Pemerintah Desa dan Perangkat Desa, Badan Permusyawaratan Desa (BPD), LPMD/LKMD, PKK, Karangtaruna, BKM/UPK PNPM, RW, RT dan kelompok masyarakat lainnya mempunyai persepsi yang sama dalam mendukung implementasi UU Desa sesuai tugas pokok fungsinya masing-masing (Suharto, 2018). Secara kuantitas sebagian besar desa saat ini kurang memiliki perangkat yang lengkap sebagaimana diatur dalam PP 43 /2014 pasal 61-pasal 64 . Sementara itu perangkat yang tersedia kapasitasnya masih perlu ditingkatkan.

Masih dirasa kurang adanya pelatihan-pelatihan khusus dan sistematis yang diberikan kepada perangkat desa maupun kelembagaan desa (BPD dll) terkait pelaksanaan (implementasi) UU Desa. Kapasitas merupakan kemampuan individual, organisasi dan sistem untuk menjalankan dan mewujudkan fungsi-fungsi secara efektif, efisien dan berkelanjutan. Dalam keberadaan desa sebagai suatu wilayah, maka kapasitas desa akan berhubungan dengan potensi yang dimiliki dalam mendukung penyelenggaraan pemerintahan (termasuk otonomi desa) misalnya sumber daya manusia, sumber daya alam, sumber keuangan ataupun manajemen pemerintahan serta partisipasi masyarakat. Dalam hubungan dengan pemerintahan desa, maka kapasitas dikaitkan dengan kemampuan pemerintahan desa (pemerintah desa dan perangkatnya serta BPD) dalam menjalankan tugas dan fungsinya secara efektif dan efisien dengan memanfaatkan potensi desa yang ada. Pemerintah Desa diharapkan memiliki kapasitas yang mendukung pelaksanaan kewenangan-kewenangan yang menjadi urusan pemerintahan desa. Hasil penelitian pada awal implementasi UU Desa tahun 2015 bahwa perkembangan kelembagaan desa di Desa Kawengen, Kec. Ungaran Timur kab. Semarang sudah memiliki beberapa jenis kelembagaan yang formal maupun non formal (Suharto, 2016) Jenis kelembagaan desa tersebut dapat dilihat dalam tabel berikut ini : 
Tabel 1. Kelembagaan di Desa Kawengen

\begin{tabular}{ll}
\hline \multicolumn{1}{c}{ Kelembagaan Desa } & Jumlah Pengurus \\
\hline Pemerintah Desa & 14 orang (Siswanto ) \\
\hline BPD & 11 orang (Muh. Sayud S.Ag) \\
\hline LPMD & 5 orang (Sarzuki) \\
\hline Karang Taruna & 15 orang (Taufik) \\
\hline PKK & 22 orang (Ktistina Sriastuti) \\
\hline BKM & 13 orang (Royan S.Ag) \\
\hline LEPED & (Sahid) \\
\hline Lembaga Daurit Tauhid & (Sutras) \\
\hline Jamaah Ahli Sunnah & (Nuroso) \\
\hline BAZIS & (Munawar) \\
\hline PUSTU (Puskesmas Pembantu) & (Bidan Nanik Supriyati) \\
\hline Posyandu & Setiap Dusun \\
\hline
\end{tabular}

Sumber : diolah peneliti, (2016)

Dengan melihat jenis kelembagaan desa yang ada yaitu Pemerintah Desa, BPD, LPMD, Karang Taruna, PKK, BKM, LEPED, Lembaga Daurit Tauhid, Jamaah Ahli Sunnah, BAZIS, PUSTU dan Posyandu, dapat dikatakan bahwa di Desa Kawengen sudah memliki hampir semua ada kelembagaan desa yang diamanatkan oleh UU Desa, yang belum ada adalah BUMDesa pada tahun itu. Yang menjadi tantangan adalah kinerja kelembagaan atau keberadaan lembaga desa tersebut apakah berkontribusi pada pembangunan kesejahteraan masyarakat desa. Hal inilah menyangkut potensi dan kapasitas kelembagaan desa di Desa Kawengen. Maka dalam rangka meningkatkan potensi dan kapasitas kelembagaan ini diperlukan suatu pola pendekatan pemberdayaan kelembagaan desa yang cocok dengan kondisi lokal desa termasuk Desa Kawengen.

Merujuk dari hal tersebut diatas bahwa Desa Kawengen saat sekarang masih perlu peningkatan dan penguatan terutama pada kapasitas perangkat desa dalam mendukung implementasi UU Desa secara mnyeluruh. Hal ini terbukti masih ada beberapa program kegiatan yang pernah berlangsung di desa ini kurang efektif misalnya Program Beras Miskin (Raskin) ternyata implementasinya dibagi rata dalam setiap kawasan RT yang ada di desa tersebut, dan masyarakat masih punya pemikiran kalau bantuan untuk orang miskin itu pada dasarnya untuk semua. Masih ada pula pola pikir atau paradigma yang membuat programprogram penanggulangan kemiskinan kurang tepat sasaran, karena setiap wilayah mempunyai kepentingan untuk mendapatkan program yang sama tanpa melihat prioritas kebutuhan dari kantong-kantong (permasalahan) kemiskinan yang ada di wilayah tersebut. Masih sangat kelihatan sebagian besar kegiatan di Desa tersebut di dominasi dan dimotori oleh Kepala Desa atau tokoh elit tertentu, hal ini sangat baik dalam rangka memanage suatu wilayah desa tetapi dari sisi pola pendekatan pembedayaan masyarakat kurang memberikan porsi masyarakat untuk berlatih kemandirian yang diamantkan di dalam UU desa tersebut. (Suharto, 2016)

Kemampuan aparat desa sangat heterogen dalam menyikapi permasalahan yang ada di Desa Kawengen. Jaringan aspirasi masyarakat terkait program atau kegiatan desa yang ada sudah cukup lancar namun masih terbatas dari jumlah pertemuan maupun masyarakat yang berpartisipasi aktif. Belum banyak kreasi, inovasi dalam pengelolaan dan pengembangan desa menuju desa yang memiliki keunggulan tetentu misalnya desa wisata, desa wisata kuliner, 
kerajinan atau home industry dan lain-lain, yang dapat mendukung peningkatan perekomian masyarakat desa. Sehingga masih perlu penguatan dan dorongan untuk membuka wacana dan pola pikir serta berkreatifitas dari seluruh perangkat dan masyrakat desa yang ada. Hal ini lah yang akan majadi kekuatan dari Kelembagaan Pemerintahan Desa pada umumnya dalam menyikapi tuntutan implementasi UU Desa berhasil dengan efektif dan optimal pada akhirnya.

Kebijakan pemerintah menetapkan arah pengelolaan pemerintahan menuju tata kelola pemerintahan yang baik (good governance) dan reformasi birokrasi, merupakan pilihan yang rasional (rational choice). Salah satu agenda besar menuju good governance dan reformasi birokrasi adalah peningkatan profesionalisme aparatur pemerintah, baik di tingkat pusat maupun sampai di tingkat desa. Dalam rangka peningkatan profesionalisme aparatur pemerintah desa, perlu diperhatikan: pengembangan kapasitas aparatur pemerintah desa dengan prioritas peningkatan kemampuan dalam pelayanan publik seperti kebutuhan dasar masyarakat, keamanan dan kemampuan di dalam menghadapi bencana, kemampuan penyiapan rencana strategis pengembangan ekonomi desa, kemampuan pengelolaan keuangan desa, dan pengelolaan kelestarian lingkungan hidup.

Peraturan Pemerintah Nomor 43 Tahun 2014 tentang Peraturan Pelaksanaan UndangUndang Nomor 6 Tahun 2014 tentang Desa berisi 91 halaman termasuk penjelasan. Peraturan Pelaksanaan UU Desa ini didalamnya mengatur tentang Penataan Desa, Kewenangan, Pemerintahan Desa, Tata Cara Penyusunan Peraturan Desa, Keuangan dan Kekayaan Desa, Pembangunan Desa dan Pembangunan Kawasan Perdesaan, Badan Usaha Milik Desa, Kerjasama Desa, Lembaga Kemasyarakatan Desa dan Lembaga Adat desa, dan Pembinaan dan Pengawasan Desa oleh Camat atau sebutan yang lainnya.

Gambar 1.1. Desain Kelembagaan

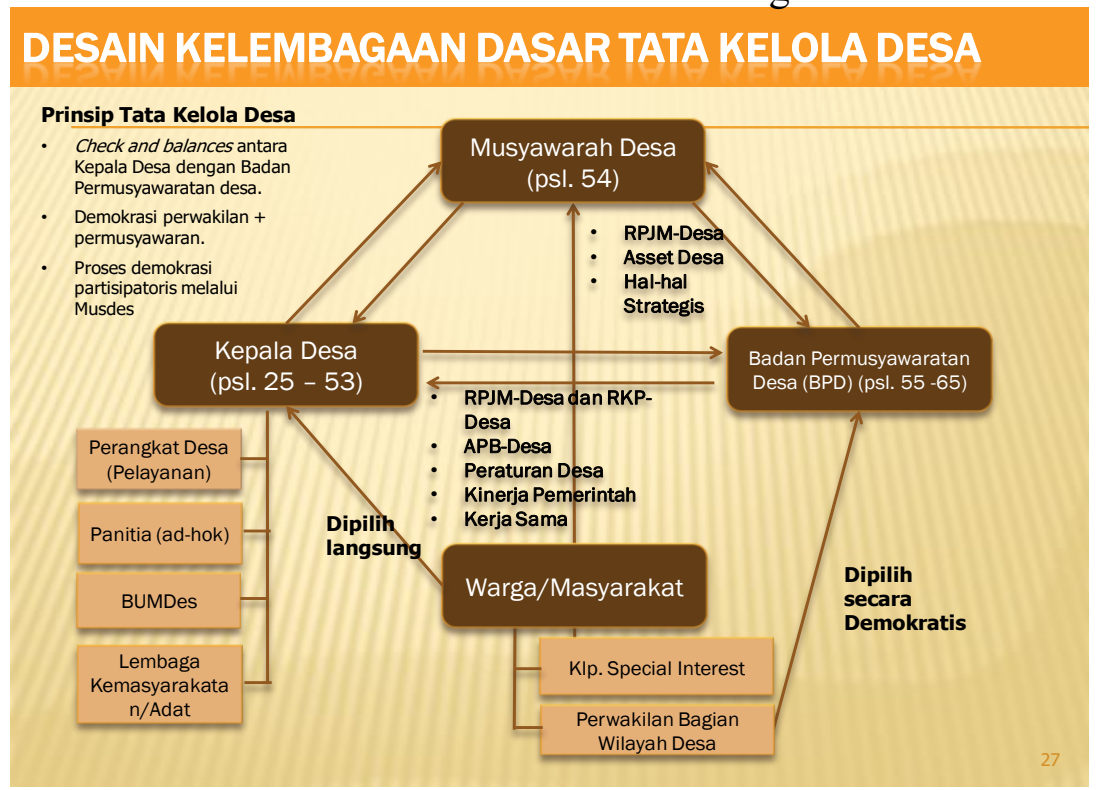

Sumber : PP No 43 tahun 2014 tentang Desa

Badan Permusyarawaratan Desa ( BPD ) yang aktif dan dinamis dalam Penyelenggaraan Pemerintahan Desa menunjukkan adanya dukungan aspirasi / kehendak masyarakat (Bottom Up) dan berjalannya fungsi Pemerintahan Desa yang efektif dalam mencapai kesejahteraan 
masyarakat desa. Dengan demikian seluruh komponen/lembaga masyarakat desa dapat menjadi pelaku utama dalam pembangunan desa dengan potensi, kemampuan yang dimiliki dan berusaha terus meningkatkan kapasitas serta kualitas menuju kemandirian desa. Dalam menjalankan pemerintahan desa, Badan Permusyawaratan Desa ( BPD ) bersama Kepala Desa mempunyai fungsi yaitu (1) mengeluarkan kebijakan; (2) mengajukan rancangan peraturan desa (Perdes), (3) menetapkan peraturan desa yang telah mendapat persetujuan bersama, (4) menyusun dan mengajukan rancangan peraturan desa mengenai Anggaran Pendapatan dan Belanja Desa (APBDes); (5) membina kehidupan masyarakat desa, (6) membina perekonomian desa, (7) mengkoordinasikan pembangunan desa secara partispasitif.

Pada dasarnya kedudukan dan peran serta Badan Permusyawarratan Desa dalam penyelenggaraan pemerintah desa, berorientasi dan mengacu peraturan perundangan pusat dan peraturan daerah ( PERDA ). Dimana kedudukan dan perannya sebagai mitra Kepala Desa dalam menentukan haluan desa dan mempunyai fungsi sangat strategis di Desa. Dengan berlakunya Undang-Undang Desa maka setiap Desa harus berbenah diri untuk mewujudkan beberapa hal antara lain peningkatan kualitas dan kapasitas dari keputusan/kebijakan desa (Peraturan Desa), kesiapan Aparatur Pemerintah desa dalam pengelolaan dan penggunaan APB Desa, serta peningkatan fungsi pelayanan masyarakat desa sesuai dengan pola pendekatan pemberdayaan masyrakat desa yang diamantkan dalam UU Desa..

Kelembagaan Desa seperti Lembaga Pemberdayaan Masyarakat Desa (LPMD) mempunyai kedudukan tugas dan fungsinya dalam menjalankan Pemerintahaan Desa yang memiliki posisi yang sanagt strategis. Pada dasarnya keberadaan LPMD merupakan unsur penunjang dan mendukung penyelenggaraan pemerintahan desa untuk pembangunan desa, yaitu menggerakkan masyarakat agar berpartisipasi aktif dalam pembangunan desa sebagai pelaku dan tidak hanya sebagai obyek pembangunan saja.. Karena tanpa partisipasi masyarakat, pemerintahan desa tidak bisa berjalan dan pembangunan desa tidak ada artinya bila masyarakat tidak dapat merasakan manfaat pembangunan desa, sehingga masyarakat harus dilibatkan yaitu dengan pola pemberdayaan masyarakat yang memposisikan masyarakat sebagai pelaku dan sebagai sasaran pembangunan desa.

Adapun tugas pokok LPMD, menyusun rencana pembangunan yang partisipatif, menggerakan swadaya dan gotong royong masyarakat untuk melaksanakan dan mengendalikan pembangunan desa. Sedangakan fungsinya menanamkan dan memupuk rasa pemersatu dan kesatuan masyarakat desa, mengkoordinasikan perencanaan pembangunan, mengkoordinasikan rencana LPMD, merencanakan kegiatan pembangunan secara partisipatif dan terpadu, penggalian dan pemanfaatan sumber daya alam untuk pembangunan desa. Kondisi secara mnyeluruh masih sebagian besar dari kedudukan tugas pokok, fungsi dan peranan LPMD di Desa, dari peran LPMD ini partisipasi dan ide gagasan lebih didominnasi juga oleh Kepala Desa dan para elit desa tertentu, yang sebenarnya harus lebih memberikan ruang partisipasi masyarakat desa. Oleh karena itu pola pikir atau paradigma dalam kelembagaan desa dan perangkat desa masih perlu penguatan dalam rangka lebih mensukseskan implementasi UU Desa yang yang sekarang ini, yang sebenarnya sudah menjadi rohnya UU Desa ini yaitu menggunakan paradigma dan pendekatan pemberdayaan masyarakat desa.

Sebagian besar di desa untuk kondisi sekarang kapasitas SDM sudah cukup tinggi bila dilihat jumlah penduduknya dan tingkat pendidikannya juga cukup merata sebagian besar 
berpendidikan SLTA dan ada beberapa yang lulus S2 dan bahkan S3. Apa lagi sudah mengenal media sosial dan familier dalam kehidupan sehari-hari sanagt berpengaruh dalam pola pemkiran masyarakat desa. Hal ini memberikan modal sosial desa dalam mengelola desa yang penuh dengan pendekatan partisipatif atau pemberdayaan masyarakat. Dari sisi kapasitas pola pikir atau paradigma masyarakat desa tetap masih perlu peningkatan, penguatan dan pencerahan kembali agar SDM yang ada semua mendukung dan peduli pada pembangunan desanya. Terdapat banyak faktor yang mempengaruhi penyelenggaraan maupun kesuksesan program pengembangan kapasitas dalam pemerintahan dan masyarakat desa..

Dengan demikian yang dapat dilakukan di desa dalam rangka meningkatkan kapasitas SDM nya secara menyeluruh, disamping dengan pemberdayaan kelembagaan desa, kesiapan SDM maupun SDA desa dan kesiapan Regulasi Desa, tetap membutuhkan kapasitas desa yang lebih kuat. Dilihat dari beberapa produk regulasi desa yang telah dihasilkan pada awal implementasi UU Desa ini pada dasarnya masih cukup terbatas. Hanya terbatas beberapa saja produk regulasi desa berupa kebijakan (keputusan) dan peraturan desa (Perdes), yang terkait dan mendukung dalam rangka suksesnya implementasi UU Desa, (Suharto, 2018)

Untuk menuju tata kelola pemerintahan desa yang baik sesuai amanat UU Desa diperlukan upaya peningkatan kapasitas kelembagaan desa nelalui model pemberdayaan kelembagaan desa yang mengarah pada kesejahteraan masyarakat yaitu desa yang berdaya dan mandiri ( Desa Berdikari ). Tata kelola pemerintah desa yang baik tercapai manakala dilakukan pemberdayaan kelembagaan desa dan pemberdayaan masyarakat desa berjalan seiring dalam rangka peningkatan kapasitas kelembagaan dan masyarakat desa, diperlukan suatu pelatihan kelembagaan maupun pelatihan kebutuhan masyarakat setempat. Hal ini jelas akan memupuk potensi dan meningkatkan modal sosial masyarakat serta menambah pertumbuhan ekonomi, infrastruktur dan kegiatan sosial atau pendidikan masyarakat. lingkungan /infrastruktur dan adanya kemandirian keuangan desa.

\section{Bagan1. Strategi Kelembagaan Pemerintahan Desa dan Pemberdayaan Masyarakat Dalam} Implementasi UU Desa

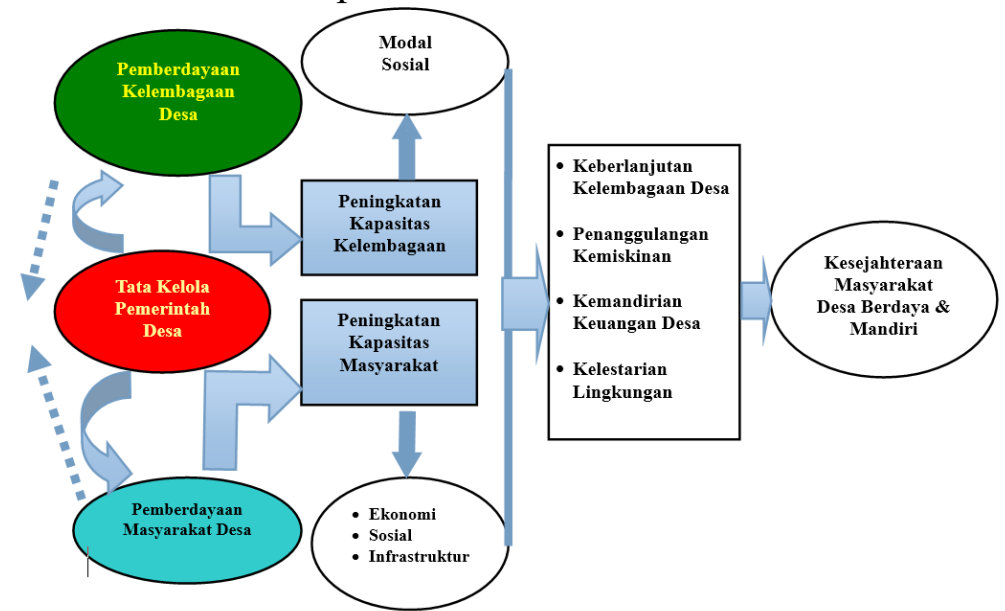

Sumber : diolah Peneliti, 2016.

Kelembagaan pemerintahan desa akan mampu mengelola mulai dari proses-proses penyusunan, pelaksanaan, evaluasi /pelaporan, pelestariannya yaitu RPJMDes, APBDes, 
pengembangan BUMDes, dan pengelolaan potensi desa yang ada. Pada akhirnya kesejahteraan masyarakat desa akan terwujud yaitu desa berdaya dan mandiri (berdikari). Secara jelas dengan melihat kondisi sekarang ini di sebagian besar desa dalam rangka implementasi UU Desa, agar kelembagaan pemerintahan Desa dan pemberdayaan masyarakat dapat berjalan optimal sesuai amanah dalam UU Desa maka langkah atau strategi yang dicapai sebagaimana dalam bagan berikut ini (Suharto, 2018). Pada dasarnya strategi dalam implementasi UU Desa tersebut, secara keseseluruhan metode pemberdayaan kelembagaan maupun masyarakat akan menuju suatu tujuan akhir kesejahteraan masyarakat desa yang berdaya dan mandiri. Hal tersebut bisa dicapai manakala tata kelola pemerintah desa menjadi baik, untuk mencapai hal tersebut tentunya di perlukan peningkatan kapasitas kelembagaan pemerintahan desa dan juga peningkatan kapasitas masyarakat desa.

Peningkatan kapasitas tersebut harus dapat menjadi satu bagian yang utuh dari upaya perubahan sosial berkelanjutan sebagai modal sosial (social capital) yang sangat berguna dalam menciptakan tata kelola pemerintah desa yang baik. Adapun strategi tersebut yaitu dengan pelatihan penguatan kelembagaan pemerintahan desa, pilot kelembagaan/best practice kelembagaan, studi banding dan pendampingan/pemberdayaan masyarakat intensif. Kebijakan pemerintah menetapkan arah pengelolaan pemerintahan menuju tata kelola pemerintahan yang baik (good governance) dan reformasi birokrasi, merupakan pilihan yang rasional (rational choice). Salah satu agenda besar menuju good governance dan reformasi birokrasi adalah peningkatan profesionalisme aparatur pemerintah, baik di tingkat pusatmaupun di tingkat desa. Dalam rangka peningkatan profesionalisme aparatur pemerintah desa, perlu diperhatikan: pengembangan kapasitas aparatur pemerintah desa dengan prioritas peningkatan kemampuan dalam pelayanan publikseperti kebutuhan dasar masyarakat, keamanan dan kemampuan di dalam menghadapi bencana, kemampuan penyiapan rencana strategis pengembangan ekonomi desa,kemampuan pengelolaan keuangan desa, dan pengelolaan kelestarian lingkungan hidup. Untuk itu, aparatur pemerintah desa patutmemahami peran strategisnya agar belajar mendalami, menggali serta mengkaji berbagai permasalahan dan tantangan pelaksanaan good governance dan reformasi birokrasi ke depan, untuk dapat diterapkan secara optimal di lingkungan kerja masing-masing.

Pengalaman menunjukkan bahwa masyarakat perlu diikutsertakan dalam upaya pengentasan kemiskinan dengan bantuan dan tuntunan pelaksana kebijaksanaan. Dalam kondisi ini harapan dan energi sosial berpadu dengan bimbingan untuk mencapai tujuan. Sikap ini menempatkan masyarakat sebagai mitra pembangunan dan bukan semata-mata sebagai penikmat hasil pembangunan. Upaya pemberdayaan masyarakat hendaknya menganut pola kombinasi pendekatan populis bottom-up dan pendekatan paternalistik top-down dalam konteks tertentu. Hal ini dimungkinkan karena kebutuhan pembangunan dapat diprioritaskan sesuai dengan kebutuhan riil. Masyarakat yang diikutsertakan dalam proses pengambilan keputusan dan implementasinya akan lebih responsif untuk turut memikul tanggung jawab pengelolaan pelaksanaan kegiatan. Hal ini akan membantu mengurangi biaya yang disediakan pihak pemerintah.

Disamping itu pengetahuan dan keterampilan lokal (indigenous technical know-how) mampu diadaptasikan untuk membantu penghematan biaya dan peningkatan keuntungan. Pemikiran di atas secara eksplisit menggambarkan keikutsertaan masyarakat sebagai mitra 
pembangunan, dan bukan lagi sebagai kelompok sasaran (obyek). Dalam keadaan ini partisipasi masyarakat sangat dibutuhkan, terutama dalam bentuk partisipasi yang bersifat mobilisasi spontan yang diartikan secara positif. Partisipasi merupakan unsur perekat dimana masyarakat merupakan faktor sentral dalam proses pembangunan desa. Partisipasi menempatkan masyarakat sekaligus sebagai mitra pembangunan, pemegang risiko (stakeholders) serta pembuat dan pengambil keputusan yang menyangkut masa depan masyarakat desa.

Upaya dan strategi pemberdayaan kelembagaan desa memiliki keterkaitan kuat dengan kondisi sosial ekonomi desa, apalagi dalam pelaksanaan UU No 6 Tahun 2014 tentang Desa. Kebijakan pemberdayaan kelembagaan hendaknya mencakup seluruh elemen sosial ekonomi dan potensi yang terdapat di desa. Dengan memahami apa yang ada di desa dan juga apa yang menjadi tantangannya akan dapat menentukan arah pengembangan desa sesuai dengan amanat UU Desa. Sehingga tidak hanya senang desa bisa mendapatkan dana desa akan tetapi bagaimana desa mampu mengelola keuangan desa tersebut dalam rangka peningkatan kesejahteraan masyarakat desa menuju desa berdaya, mandiri atau berdikari dalam arti sesungguhnya.

\section{KESIMPULAN}

Pada dasarnya Undang Undang No. 6 Tahun 2014 Tentang Desa memberi amanah kepada Pemerintah, Pemerintah Provinsi, Pemerintah Kabupaten / Kota dan kelembagaan pemerintahan desa untuk menggunakan pola pendekatan pemberdayaan masyarakat dalam pembangunan desa menuju kemandirian desa dan kesejahteraan masyarakat desa. Kelembagaan pemerintahan desa dan pemberdayaan masyarakat desa merupakan kunci dari berhasilnya pembangunan desa sesuai amanah dari UU desa, menuju kemandirian desa. Maka kinerja kelembagaan pemrintahan desa perlu mendapatkan dukungan yang signifikan dari semua fihak yaitu kepedulian / partisipasi dari masyarakat desa, para stakholders yang ada, pengusaha/swasta, pemerintah dan kadalangan perguruan tinggi seta kelompok peduli lainnya. Dalam rangka implementasi UU Desa menuju tata kelola pemerintahan desa yang baik sesuai amanat UU Desa, maka sebaiknya diperlukan upaya peningkatan kapasitas kelembagaan pemerintahan desa dengan strategi pemberdayaan masyarakat dan kelembagaan pemerintahan desa yang mengarah pada kesejahteraan masyarakat yaitu desa yang berdaya dan mandiri ( Desa Berdikari ). Hal ini dilakukan harus dengan pemberdayaan kelembagaan pemerintahan desa dan pemberdayaan masyarakat desa dan juga harus berjalan seiring dalam rangka peningkatan kapasitas kelembagaan dan masyarakat desa sesuai amanah UU Desa.

\section{DAFTAR PUSTAKA}

\section{Buku dan Jurnal}

Aspariyana, A. (2018). Dampak Modernisasi Perilaku terhadap Budaya. Teraju Umrah. https://teraju.umrah.ac.id/dampak-moderenisasi-perilaku-terhadap-budaya/

Dye, T. (1972). Understanding public policy. Prentice-Hall.

Hair, J. F., Black, W. C., Babin, B. J., \& Anderson, R. E. (2010). Multivariate Data Analysis; a global perspective (Seventh Ed). Pearson Education Limited. 
Hogwood, B. W., \& Gunn, L. A. (1984). Policy analysis for the real world. Oxford University Press.

Lindblom, C. E., \& Woodhouse, E. J. (1993). The policy-making process (3rd ed.). Prentice Hall.

Moleong, L. J. (2012). Metodelogi penelitian kualitatif. Remaja Rosdakarya.

Parsons, W. (1992). Public policy: An introduction to the theory and practice of policy analysis. Elgar.

Rizkita, S. (2016). Akuntabilitas pemerintah desa. Kedesa.Id. http://kedesa.id/id_ID/akuntabilitas-pemerintah-desa/

Solichin, A. W. (2008). Analisis Kebijakan: Dari Formulasi ke Implementasi Kebijakan Negara. Jakarta: Bumi Aksara.

Solichin, A. W. (2012). Analisis kebijakan: Dari formulasi ke penyusunan model-model implementasi kebijakan publik. Bumi Aksara.

Sugiyono. (2012). Metode penelitian kuantitatif, kualitatif, dan $R \& D$. Alfabeta.

Suharto, S. (2018). Kapasitas Pemerintahan Desa Dalam Implementasi Undang-Undang Nomor 6 Tahun 2014 Tentang Desa Di Jawa Tengah. Sosio Dialektika, 3(2).

Suharto, S. (2021). Kesiapan Desa Dalam Implementasi UU Nomer 6 Tahun 2014 Tentang Desa (Studi Kasus Di Desa Kawengen Kec. Ungaran Timur Kab. Semarang) (Doctoral dissertation, Universitas Wahid Hasyim Semarang).

Sujarweni, V. (2015). Akuntasi desa panduan tata kelola keuangan desa. Pustaka Baru Press. Tangkilisan, H. N. S. (2003). Kebijakan publik yang membumi. Yogyakarta: Lukman Offset. Topatimasang, D. K. K. (2000). Merubah Kebijakan Publik.

Wahab, S. A. (2012). Analisis kebijakan: Dari formulasi ke penyusunan model-model implementasi kebijakan publik. Bumi Aksara.

Weimer, D. L., \& Vining, A. R. (2017). Policy analysis: Concepts and practice. In Policy Analysis: Concepts and Practice. Taylor and Francis. https://doi.org/10.4324/9781315442129 